\title{
Strengthening Good Governance through Institutionalization of SATRIYA Codes of Conduct: A Lesson from Yogyakarta Special Region
}

\author{
Ambar Teguh Sulistiyani \\ Departement of Public Policy and Management \\ Fakultas Ilmu Sosial dan Ilmu Politik UGM \\ Yogyakarta, Indonesia \\ atsulis@yahoo.co.id \\ Agnes Sunartiningsih \\ Departement of Social Development and Welfare \\ Fakultas Ilmu Sosial dan Ilmu Politik UGM \\ Yogyakarta, Indonesia \\ agnes@ugm.ac.id
}

\author{
I Made Krisnajaya \\ Departement of Public Policy and Management \\ Fakultas Ilmu Sosial dan Ilmu Politik UGM \\ Yogyakarta, Indonesia \\ imadekrisnajaya2015@gmail.com \\ Kristi Yuliani \\ Departement of Public Policy and Management \\ Fakultas Ilmu Sosial dan Ilmu Politik UGM \\ Yogyakarta, Indonesia \\ yuliani.kristi@gmail.com
}

\author{
Muammar Yuliana \\ Departement of Public Policy and Management \\ Fakultas Ilmu Sosial dan Ilmu Politik UGM \\ Yogyakarta, Indonesia \\ moeammary@gmail.com
}

\begin{abstract}
Bureaucratic reform in Indonesia has been developed on the principles of good governance which include efficiency, effectiveness, responsiveness, accountability, and ethical conduct. In Yogyakarta Special Region, the provincial government put emphasis on improving personnel capacity and competence as well as strengthening bureaucratic codes of conduct, which paved the way for the prominence of ethical conduct principles as a key success of bureaucratic reform. The institutionalization of SATRIYA codes of conduct has therefore become provincial government's flagship program since 2008 . SATRIYA codes of conduct were formally established through Governor Regulation No.72/2008 on Government Codes of conduct in Yogyakarta Special Region. It also complies with Law No.13/2012 on Yogyakarta's Special Status and Minister of Administrative and Bureaucratic Reform Decree No.39/2012 on Guides of Work Codes of conduct Development. As a set of codes of conduct, SATRIYA has been promulgated intensively in all units and levels of Yogyakarta Special Region government. The institutionalization of SATRIYA has been evaluated regularly in order to ensure its success and continuity. The institutionalization of good governance principles requires a relevant transmission media value. In conclusion, SATRIYA has a significant contribution in establishing good governance in Yogyakarta Special Region. Moreover, SATRIYA has become a model of best practice at national level.
\end{abstract}

Keywords - Institutionalization;

SATRIYA

Codes;

\section{INTRODUCTION}

The codes of conduct of Government's organizationreferred further as Government codes of conduct-are important element that put the system of values and behavior into the heart of civil servants. Government codes of conduct were built based on the leaders' vision and ideals. Intentional or not, codes of conduct is formed in the government system due to internal and external interactions. The proper and orderly Government's organization, everlastingly tries to build codes of conduct. The codes of conduct arrangement is idealized by the leaders is based on the norms and values as well as the institutionalized local wisdom.

The efforts to achieve good governance in provincial government require codes of conduct. Behavior of work, procedures of tasks, and functions of the local government organization (note: OPD) to some extent depend on the codes of conduct actualization. Good governance set of values or principles is institutionalized to the level of individual, division, and organization. The institutionalization of good governance principles requires a relevant transmission media value. SATRIYA codes of conduct has been used as a sharpener of the mindset, attitudes and cultural behavior that are truly relevant with the good governance principles.

The Government of Yogyakarta Special Region has initiated perceptible program to institutionalized SATRIYA in 
its bureaucracies. SATRIYA has been formally established through the Governor Regulation of Yogyakarta No. 72 of 2008 [1], which aimed at developing value system and behavior of civil servants. The main objective of the implementation of Governor Regulation is to form civil servants' mindset, attitude, and behavior in their daily lives based on SATRIYA.

SATRIYA is also expected to play important role in improving the privileges of Yogyakarta Special Region. It was derived from the values developed by the struggling Sultan Hamengkubuwono I during the Dutch colonialist occupation in Yogyakarta region. As seen from its historical background, SATRIYA represents the once and continuously emerging values of nationalism. These values have been accepted as a strategic source of norms and acculturated values in Yogyakarta Special Region government organizations.

The main method used quantitative research, by distributing questionnaires-survey to 350 respondents. In addition, it used focus-group discussion and depth interview to obtain more detailed information. Data from the survey were processed with SPSS method and were analyzed using descriptive statistics. While the data from focus-group discussion and in-depth interview were analyzed using qualitative descriptive.

\section{The principles of good governance in bureaucratic reform}

A sustainable bureaucratic reforms generally involves structural, administrative, and cultural approaches. The practice of good governance in bureaucracy is usually supported by three pillars: government, private sectors, and civil society. The contributions of the private sectors and civil society are largely in promoting participation in public affairs administration.

Alm (2013) [2] stated that the meaning of good governance is scheduled especially on the achievement in building a good governance system; the coverage of good governance is epitomized by predictable, open and enlightened policy making, a bureaucracy imbued with a professional ethos; an executive arm of government accountable for its actions; and all behaving under the rule of law.

Actualizing good governance in accordance with the opinion of the UNDP (1997) [3] are participation, rule of law, transparency, equity, responsiveness, consensus, orientation, efficiency, effectiveness, accountability and strategic vision. These ten principles of good governance can be realized if supported by good capacity, capability and codes of conduct. World Bank (1997) [4] perceive good governance as the implementation of development management which are solid, responsible, suitable with the principles of democracy, market efficiency, proper allocation of investment funds, preventing the corruption from political and administrative aspects, be discipline in running budgets, and create a legal and political framework for the growth of business activities.
The UNDP and World Bank's principles of good governance do not only require competent and professional civil servants, but also the apparatus' supportive mentality, soft skills and talents (World Bank, 1994) [5]. Civil servants' mentality and proficiency are formed of psychological maturity which should be balanced with professionalism. The elements that formed the civil servants' mentality are genetic aspects (innate nature), life experiences and environmental influences.

Regarding the above understandings of good governance, this study focuses on SATRIYA codes of conduct as a strategic instrument in establishing good governance in the bureaucracy. Below is the achievement of good governance which was measured by Indonesian Governance Index (2015).

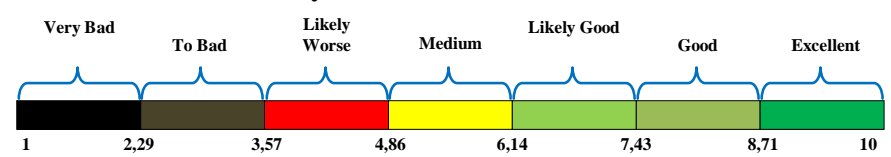

Fig 1. Indonesia Governance Index Scale

Source: IGI, Performance Yogyakarta Provincial Governance (2015)

IGI scale consists of seven classification of score; 1-2.29 (very bad); 2.30 to 3.57 (bad); 3.58 to 4.86 (likely worse); 4.87 to 6.14 (medium); 6.15 to 7.43 (likely good); 7.44 to 8.71 (good); and 8.72 to 10 (excellent). Contributions of Government codes of conduct in achieving good governance index can be seen from the score achieved.

Iii. System of values and norms in the constellation of bureaucratic codes of conduct

There are values established by the organization leader, which includes the interaction process between internal and external parties. Internal interaction usually takes place among individuals, between individuals and groups, and between groups. It forms the perception, image, relationship, values, and agreements whether they are written or unwritten. The results of continuous interaction represent the system of values and attitude of organizational codes of conduct As stated by Robin (2000) [6], "organizational behavior studies three determinants of behavior in organization: individuals, groups, and structure". Bauer and Erdogan (2012) [7] stated, "...organizational behavior includes examining the individual, the group and the organization".

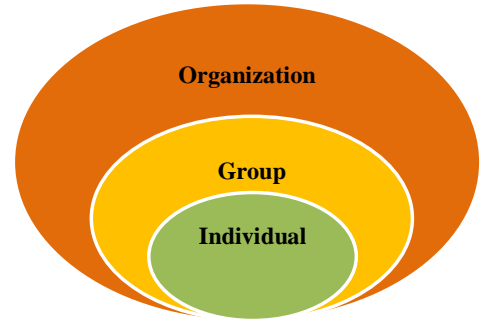

Fig 2. Organizational behavior.

Source: Bauer and Erdogan (2012)

The system of values and behaviors that entrenched in the organization can be influenced by the domination of the individual and group elements. If there is a cooptation in certain individual or group, it will bring out the personification 
of the organization. If the source is fragmented into several forms and orientations that are not dominant, then the organizational codes of conduct will be fragmented. According to Hodgetts and Luthans (2003) [8], the different characteristics of codes of conduct are determined by the innate nature of individuals as well as the groups that exist therein. Shahzad (2012) [9] stated, "Researches shows that every individual in the organization has different codes of conduct and he or she first tray to adjust him with the norms and values of the organization".

Organizational codes of conduct contribute to the success of employee's performance. The organization of government cannot be separated from the influence of the system of values and norms. As mentioned by Stewart (2010) [10], "organization's norms and values have a strong effect on all of those are attached with the organization". Based on Stewart's concrete opinion, he clarified that all norms and values form beliefs and establish the way to behave in all elements of the organization. The influence of norms and values are powerful so as to form a working behavior. Norms and values of the organization attracts everyone to do something desired and determined by organization, and avoid the prohibitions that are not detrimental to the organization.

The main goal of the organization is to form the high employee's performance. the improvement of performance is done by optimizing the positive values to establish work ethic. Applied form of the norms and values are inherent in the behavior. if the developing norms and values within the organization is positive, then the apparatus' behavior must support the performance. Based on Stewart's opinion (2010) [10], he stated that, "norms are invisible but if the organizations want to improve the performance of the employees and profitability, norms are places first to look". In accordance to Robbins (2000) [6], "behavior in order to make organizations work more effectively".

The positive institutionalized norms and values, form a productive working codes of conduct. In contrast, negative norms and values cause counterproductive working codes of conduct. If the norms and values are weak, then the organizational climate is less conductive. It makes the employee's performance tends to be low. According to Kanten and Funda (2013) [11], "Organizational climate is one of the organizational factors that affect counterproductive behaviors". Ndraha (2003) [12] stated that the corporate codes of conduct is the application of organizational codes of conduct toward enterprise as well as government organization. The Government codes of conduct like two sides of a coin. According to Kolade (2014) [13], Some indicator to measure the successfulness in establishing government codes of conduct can be seen through five variables, such as altruism, conscientiousness, courtesy, sportsmanship and civic virtue

Organization has the differences in value systems and norms. It surely form the different patterns. Specifications of the organization's values and norms reduce certain codes of conduct. As exemplified by Kolade (2014) [13], "hospital corporate image has three components, corporate identity, corporate communication and perceived quality". In creating a conducive environment, government's organization requires the role of regulation to achieve the principles of good governance. The adoption of the values of good governance is attempted to improve the quality of the apparatus, commitment to the task, and the implementation of organizational. appropriately and optimally. Shazad (2012) [9] said that the adoption of the codes of conduct of organization is helpful for the employees to done their work efficiently and effectively. It is simply stated that the adoption of organizational codes of conduct facilitates employees to work efficiently and effectively. Compatible with the statement of Kolade (2014) [13], "the four factors of the organizational performance are service efficiency and satisfactions".

Ensuring the effectiveness of the organizational codes of conduct in determining the employee's performance can be seen through the obedience of the employees. The higher employee's obedience towards norms and values, it will make the commitment be high also. In accordance to Dunn's opinion (2004) [14], "Compliance: monitoring in the case of the function of compliance helps to determine if the processes, activities and resources, staff, and others involved are in compliance with the standards and procedures that are defined in advance either by the organization itself or the external environment". Obedience determines the successfulness of the organization on the one hand and the performance of employees on the other side. The high obedience of employees reflects the effective working codes of conduct in supporting good governance.

Iv. Government codes of conduct in promoting the objectification of good governance in yogyakarta

\section{A. Commitment of Regulation}

SATRIYA covers the prime values to form the character, attitude, and individual behavior as individual and civil servants. SATRIYA philosophical reference is "hamemayu hayuning bawana", which means to protect, preserve, and maintain the safety of the world, and also concerned more in serving the society rather than to fulfill personal needs. SATRIYA can be viewed in two ways. Firstly, it represents a chivalrous character that upholds the Javanese moral teachings such as sawiji, greget, sengguh ora mingkuh and golong gilig (focus, passionate, friendly, be responsible). Secondly, it is an acronym which stands for the principles of harmony, being intellectual, become exemplary, willingness to serve, innovative, self-confident, and professional. All of these principles are broke down into some indicators as stated in Governor Regulation No. 72 of 2008 [1].

The institutionalization of SATRIYA should take place in at least three stages as stated in Governor Regulation No. 53 of 2014 [15]. The first stage is the formulation of cultural values which cover a series of complete, clear, and enabling indicators. These indicators are expected to be compatible with the principles of good governance. Secondly, the implementation of SATRIYA includes the declaration, socialization, and continuous internalization in order to 
promote good governance in the workplace. Thirdly, to monitor and evaluate the implementation of SATRIYA in order to measure the achievements of cultural change which is supposed to accelerate good governances embodiment.

Implementation of SATRIYA is supported by local and national regulations. Some of these regulations are (1) Regulation of State Minister for the Empowerment of State Apparatus No 1 of 2007 [16] on Guidelines for the Evaluation of the Working Codes of Conduct Development in Government's Agencies; (2) Regulation of State Minister for the Empowerment of State Apparatus and Bureaucratic Reform Republic of Indonesia No. 39 of 2012 [17] on Guidelines for the Development of Working Codes of Conduct; and (3) Regulation of State Minister for the Empowerment of State Apparatus and Bureaucratic Reform Republic Indonesia No. 27 of 2014 [18] on Guidelines for the Development of Agent of Change in Government Agencies.

\section{B. SATRIYA Codes of Conduct and Good Governance}

SATRIYA has been viewed as a new spirit in achieving good governance in government agencies. As stated by the Chairman of Yogyakarta Special Region DPRD, "SATRIYA has been a great contribution for the achievement of good governance" (Workshop SATRIYA codes of conduct 2014). The institutionalization of SATRIYA became the first best practice of the implementation of government codes of conduct in Indonesia. The seriousness of the Yogyakarta Special Region government in institutionalizing SATRIYA is shown by the agenda of policy on a macro and micro scale, especially in the medium term development plan 2011-2016, and also the work program of Organization Bureau.

The institutionalization of SATRIYA in the group, division or organization has been carried out by a taskforce acting as agents of change through programs of socialization, internalization, dissemination, and advocacy. The agents of change set up action plans in order to mobilize and monitor the implementation of SATRIYA. The development of SATRIYA in 23 local government agencies through the valuation of socialization and internalization has improved. Leadership aspects are increased by 22 OPD and decreased by 12. Mindset and working manner aspects are increased by 18 including one fixed OPD and 15 are decreased. On the implementation of SATRIYA, OPD has increased by 18 including one fixed Organization and 15 decreased Organizations. Generally, the development of the value in every aspect can be seen from this percentage as follows.

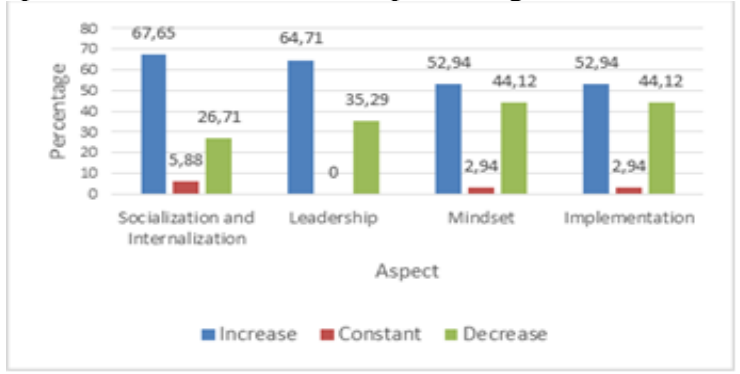

GRAPHIC I. THE PERCENTAGE OF SATRIYA CODES OF CONDUCT IMPLEMENTATION DEVELOPMENT IN 2014-2015.
The problem faced in institutionalizing SATRIYA is the readiness of OPD in supporting and realizing it. On the one hand, rising score in the implementation of SATRIYA in several OPD covers almost all aspects. On the other hand, the score also degraded in some aspects. However, generally the number of OPD that increased in three aspects has more valuation than the one that fixed or degrading in score. Unfortunately, the achievement of SATRIYA yet to be optimal as well as the achievement of good governance. In 2015, the achievement of IGI in Government of Yogyakarta Special region is:

TABLE I. ACCOMPLISHMENT OF IGI IN GOVERNMENT OF YOGYAKARTA (2015) PER ARENA AS SEEN FROM THE GOOD GOVERNANCE INDICATOR ASPECTS

\begin{tabular}{|c|c|c|c|c|c|c|c|}
\hline Stakeholders & $\begin{array}{l}\text { Index } \\
\text { (per } \\
\text { Arena) }\end{array}$ & $\begin{array}{l}\text { Parti } \\
\text { cipat } \\
\text { ion }\end{array}$ & $\begin{array}{l}\text { Equi } \\
\text { ty }\end{array}$ & $\begin{array}{l}\text { Acco } \\
\text { unta } \\
\text { bilit } \\
\text { y }\end{array}$ & $\begin{array}{l}\text { Tra } \\
\text { nsp } \\
\text { are } \\
\text { ncy }\end{array}$ & $\begin{array}{l}\text { Effic } \\
\text { ienc } \\
\mathbf{y}\end{array}$ & $\begin{array}{l}\text { Eff } \\
\text { ecti } \\
\text { ven } \\
\text { ess }\end{array}$ \\
\hline Government & 6,52 & 6,40 & $\begin{array}{r}* * 2, \\
94 \\
\end{array}$ & $\begin{array}{r}* * 8, \\
37 \\
\end{array}$ & 7,97 & 6,70 & $\begin{array}{r}5,8 \\
8 \\
\end{array}$ \\
\hline Bureaucracy & 7,46 & $\begin{array}{r}* * 9, \\
55 \\
\end{array}$ & 7,38 & 7,73 & $\begin{array}{r}* * 9, \\
09 \\
\end{array}$ & $\begin{array}{r}* * 5, \\
42 \\
\end{array}$ & $\begin{array}{r}5,8 \\
7 \\
\end{array}$ \\
\hline Civil Society & 6,72 & 7,64 & 6,40 & 6,40 & 6,40 & 6,40 & $\begin{array}{r}7,0 \\
3 \\
\end{array}$ \\
\hline Business & 6,12 & 6,40 & 6,40 & 6,40 & 6,40 & 6,40 & $\begin{array}{r}* * 4 \\
, 61 \\
\end{array}$ \\
\hline
\end{tabular}

The Government stakeholder, bureaucracy, civil society and economic society are measured using good governance indicators such as participation, equity, accountability, transparency, efficiency and effectiveness. As shown in Table I, good rating is awarded in the aspect of government, civil society, and economic society. Judging from its performance indicators, the highest score is participation. It is followed consecutively by accountability, transparency, efficiency, effectiveness, and justice. Despite the negative impression, there are some indicators which reached highest score at the national level, namely bureaucratic participation, bureaucratic transparency, and government's accountability (see Graphic II). However the lowest score are government's equity, bureaucratic efficiency, and the effectiveness of economic society.

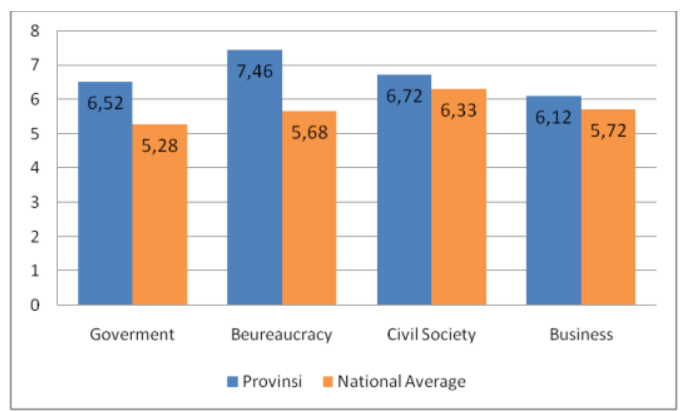

GRAPHIC II. TO NATIONAL AVERAGE

Source. IGI, Yogyakarta's Provincial Performance (2015)

Overall, government of Yogyakarta's good governance has a higher score if compared with the national average. Those score shows the indicator of accumulative calculations per 
coverage. In noticing the evaluation of SATRIYA that yet to be optimal, it is reveals that the performance of OPD is nothing better. This paved the way for their limited contribution in the achievement of good governance. Although the value of IGI surpassing the national average and some of the accomplishments can be achieved on a national stage - the first rank of national performance (score-47.51) and second rank of national achievement of the MDGs - but there are several governance indicators that lame such as the indicator of government's equity, bureaucratic efficiency, and the ineffectiveness of the private sector. Meanwhile, that score is the lowest in the national level. The optimization of SATRIYA is monitored intensively in all OPD in order to improve the government codes of conduct and Yogyakarta's governance index.

\section{CONCLUSION}

The role of SATRIYA codes of conduct has not been optimal in achieving good governance in Yogyakarta Special Region. However SATRIYA codes of conduct contributed towards good governance implementation. Several principles of good governance Government of Yogyakarta Special Region has the highest value on a national level. Accumulatively, there are more OPDs that committed to implement SATRIYA in order to promote ethical character, attitude, and behavior. The limited contribution accounts for the limited accomplishment of governance index. Although IGI Government of Yogyakarta's score is accumulatively above the national average, but all the indicators are categorized as "likely good". Things should be improved are the worsening government equity index, mediocre bureaucratic efficiency, and ineffectiveness of the private sector. The degrading score of OPD shows lack of the leader's commitment in implementing SATRIYA codes of conduct. Based on these results, then the recommendation is important to increase the commitment all of the leadership in OPDs. Intensification of implementation of codes of conduct SATRIYA is extended to all employees, in the form of real work behavior.

\section{ACKNOWLEDGMENTS}

The purpose of this reseach was to investigate the application of SATRIYA codes of conduct in the context of good governance. The result of this study identifies the SATRIYA codes of conduct in supporting the achievement of good governance in Yogyakarta Special region. Based on the fact that the SATRIYA code of conduct gave contribution in establishing good governance, thus it has been arranged recommendation for improvement.

\section{REFERENCES}

[1] Peraturan Gubernur Daerah Istimewa Yogyakarta No 72 Tahun 2008 tentang Budaya SATRIYA (reference)

[2] Alm. Jens. (ed), 2013. Action for Good Governance in International Sports Organizations. (Final Report. April, 2013). Copenhagen: Play the Game/Danish Institute for Sports Studies.

[3] UNDP. 1997. Tata Pemerintahan yang Baik dari Kita untuk Kita. Jakarta: UNDP. [7] Bauer. Talya. and Berrin Erdogan. 2012. An Introduction to Organizational Behavior. (v.1.1. December 29, 2012). Downloaded then bu Andy Schmitz. http://lardbucket.org

[4] World Bank, 1997, World Development Report 1997, the State in the Changing World, Washington: World Bank.

[5] Wold Bank. 1994. Governance: The World Bank's Experience. Washington DC: World Bank Publications

[6] Robbins. Stephen P. 2000. 9th. Organizational Behavior. Published by Prentice Hall Upper Saddle River.NJ.

[7] Bauer. Talya. and Berrin Erdogan. 2012. An Introduction to Organizational Behavior. (v.1.1. December 29, 2012). Downloaded then bu Andy Schmitz. http://lardbucket.org

[8] Hodgetts and Luthans.F. 2003.5th. International Management: Culture, Strategy, and Behavior. New York. McGraw-Hill/Irwin.

[9] Shahzad. Fakhar. Rana Adeel Luqman. Ayesha Rashid Khan. And Lalarukh Shabbir. 2012. "Impact of Organizational Cultur on Organizatinal Performance: An Overview", Interdisciplinary Journal of Contemporary Research in Business. (Vol.3. No: 9. January 2012). Copy Right 2012 Institute of Interdisciplinary Business Research. pp: 975985. (reference)

[10] Stewart. Douglas. 2010. Growing the Corporate Culture. obtained from https://www.wachovia.com/foundation/v/index.jsp?vgnextoid=ab411f07 76aa110VCMI000004b0d1872. RCRD \& vgnextfmt. Default on January 10th.2011.

[11] Kanten.Pelin and Funda Er Ulker. 2013. "The Effect of Organizational Climate on Counterprodustive Behaviors: An Empirical Study on the Employees of Manufacturing Enterprises". The Macrotheme Review 2(4): A Multidiciplinary Journal of Global Macro Trends.(summer 2013).pp: 144-160. (reference)

[12] Ndraha. Taliziduhu. 2003. Teori Budaya Organisasi. Jakarta: Rineka Cipta.

[13] Kolade.Obamaro John. Ogunnaike Olaleke. And Osibanjo Omotayo.2014.”Organizational Citizenship Behaviour, Hospital Corporate Image and Performance." Journal of Competitiveness.(Vol.6 Issue 1. March 2014). pp: 36-49

[14] Dunn. W. 2004. Public Policy Analysis : An Introduction. Prentice Hall. Upper Saddle River.

[15] Peraturan Gubernur DIY No 53 tahun 2014tentang Pedoman Pelaksanaan Budaya Pemerintahan (reference)

[16] Peraturan Menteri Negara Pendayagunaan Aparatur Negara No 1 tahun 2007 tentang Pedoman Evaluasi Pelaksanaan Pengembangan Budaya Kerja pada Instansi Pemerintah.

[17] Peraturan Menteri Pendayagunaan Aparatur Negara dan Reformasi Birokrasi No 39 Tahun 2012 tentang Pedoman Pengembangan Budaya Kerja.

[18] Peraturan Menteri Pendayagunaan Aparatur Negara dan Reformas Birokrasi Republik Indonesia No 27 tahun 2014 tentang Pedoman Pembangunan Agen Perubahan di Instansi Pemerintah. 